\title{
Effects of Joint Therapy Mobility Exercises on The Level of Osteoarthritis Knee Joint Pain in The Elderly Padang Posyandu
}

\author{
Rachmawaty M Noer ${ }^{1}$, Ika Sheilla ${ }^{2}$ \\ ${ }^{1,2}$ Nursing, STIKes Awal Bros Batam, Indonesia \\ ${ }^{1}$ rachmawatymnoer1977@gmail.com, ${ }^{2}$ Ikasheilla@gmail.com
}

\begin{abstract}
(
Keywords:

Osteoarthritis;

Exercise Theraphy Joint Mobility.

ABSTRACT

Osteoarthritis (OA) is a degenerative joint disease, where the overall structure of the joint undergoes pathological changes. One of the changes that occur in the musculoskeletal system can cause mobility disorders. The impact that will occur in the elderly with osteoarthritis is likely to experience a decrease in musculoskeletal function. This study aims to determine the effect of osteoarthritis knee joint pain levels before and after exercise therapy for joint mobility. The design of this study uses a quasiexperimental method with a Pre and Post Test without Control research design. The sample in this study consisted of 30 respondents. The sampling method in this study is accidental sampling. Research data were analyzed using the Wilcoxon test. It is known that more than half of respondents who have osteoarthritis are in the age range of $45-59$ years, which is $46.7 \%$ (14 respondents). The results showed that in general osteoarthritis pain before ROM was in the range of $80 \%$ moderate pain, and the results showed that in general osteoarthritis pain after ROM was in the range of $76.7 \%$. Data analysis found that the $\mathrm{p}$-value was $0,000(\mathrm{p}=<0.05)$ indicating that there was an effect of exercise joint mobility on the level of osteoarthritis knee joint pain in the elderly in the Posyandu of the Belakang Padang elderly. This research is expected to be able to contribute and develop nursing, as a material for making policies on psychological approaches in the form of exercise therapy for joint mobility in overcoming joint pain in patients with osteoarthritis. osteoarthritis by involving variables that affect the level of pain.
\end{abstract}

Article History:

Received: 04-03-2018

Revised : 28-03-2018

Accepted: 29-04-2018

Online : $30-04-2018$

\author{
This is an open access article under the CC-BY-SA license \\ Crossref \\ https://doi.org/10.31764/ijeca.v1i1.2098
}

\section{A. INTRODUCTION}

Elderly person is someone who has entered the age of 60 years and above. The elderly is a group of age in humans who have entered the final stages of its life phase. Groups categorized in this elderly there will be a process called Aging process or the aging process (WHO, 2015) Elderly are individuals who are in the stage of the final adult age, with age above 60 years. The elderly is defined also as a decline, immolation, increased susceptibility to various diseases and Environmental changes, loss of mobility and dexterity, and age-related physiological changes. (Candra Widyanto, 2014)

One of the elderly stages is the aging process, where the aging process is a cycle of life characterized by the declining stages of various functions of the body organs, which are 
characterized by the increasing range of the body against various disease attacks that can cause death eg in the cardiovascular system and blood vessels, respiratory, digestive, endocrine and other

Etc. This is due to the increasing age resulting in changes in the structure and function of cells, tissues, and organ systems. These changes generally point to the decline of physical and psychic health that will eventually affect the elderly economy and social. So it will generally affect the activity of daily living (Nugroho Wahjudi, 2015).

Elderly tend to decline in musculoskeletal function. The function of a joint cartilage has decreased so that the cartilage will thin and result in joint stiffness. Joint stiffness when not immediately treated can interfere with physical mobility in the elderly. Joint muscle when used to move then synovial fluid will increase and increase so that the elderly do the activity well. When muscle joints are not used to perform the activity, this synovial fluid will remain, thus, not increased (Theresia, 2014).

Based on the prevalence of data an estimated 15.8 million (12\%) Adults between 25-74 year experience symptoms such as osteoarthritis (Spetz, Tellez, \& Fulton, 2016). The prevalence and severity of osteoarthritis differ between the age range of adults and the elderly. As an overview, the prevalence of osteoarthritis of the hands is $20 \%$ in patients under 45 years and only $8.5 \%$ at the age of 75-79. Conversely, osteoarthritis of the knee occurs $<0.1 \%$ in the $25-34$ year group from $10-20 \%$ in the $65-74$ year group. Moderate knee osteoarthritis until the weight of $33 \%$ patients aged 65-74 years and moderate pelvic osteoarthritis to the weight experienced by $50 \%$ patients with the same age range. The National Arthritis Data Work Group by using The First National Health and Nutritional Examination Survey (HANES I) and other Data predicted, that in 2020 Estimated $18.2 \%$ of the American community will suffer osteoarthritis. Women in America are apparently more often affected by osteoarthritis by doubling than men. Based on his dance involvement, Osteoarthritis is most commonly found in the knees, hands, and pelvis. According to Framingham's cohort study, the prevalence of symptomatic Osteoarthritis of the hands of $6.8 \%$, knee $4.9 \%$, and pelvic $4.3 \%$. Meanwhile, Radiographic Osteoarthritis is found as much as $19.2 \%$ in the knee, $27.2 \%$ in the hands, and $19.6 \%$ in the pelvic. This figure differs from the Johnston County Osteoarthritis Project (JCOP), in which the prevalence of symptomatic Osteoarthritis is found as much as $16.7 \%$ in the knee and $9 \%$ in the pelvic. In China, Osteoarthritis is most commonly found to occur in the knee joint.

Based on data from Central Statistics Agency (Badan Pusat Statistik, 2014) the elderly population in Indonesia reaches 20.24 inhabitants equal to $8.03 \%$ of the entire population of Indonesia. Increasing the number of elderly people showed that the age of life expectancy in Indonesia is higher year after year. The number of elderly women is 10.77 million elderly, and elderly men 9.47 million elderly. From the results of the data shows that the pain of the joints is enough to interfere with the activity of Indonesian people, especially in the elderly as we grow older. According to basic health Research (RISKESDAS 2013), the most diseases experienced by the elderly are hypertension (57.6\%), arthritis (51.9\%),and stroke (46.1\%). In Indonesia, the number of osteoarthritis disease is $5 \%$ at the age of $<40$ years, $30 \%$ at the age of $40-60$ years, and $65 \%$ at the age of $>61$. According to Riskesdas in 2013, the number of joint disease prevalence is based on a diagnosis of $11.9 \%$ and based on the symptoms $24.7 \%$. When viewed from age characteristics, the highest prevalence at age $\geqslant 75$ years $(54.8 \%)$.

Female sufferers also more (27.5\%) Compared to men (21.8\%) (Flower, 2015) The national precondition of joint or osteoarthritis disease is $30.3 \%$ and the prevalence based on nakes ' diagnosis is $14 \%$. The pravalency of joint disease osteoarthritis showed, $17.6 \%$ of the population of Riau archipelago suffered joint interference, and this figure is still under national pravalency of $22.6 \%$. While the pravalency of joint disease osteoarthritis based on the diagnosis by health personnel is $9.5 \%$. Which is still below the fate of $15.02 \%$. According to the regency of the city, the prevalence of joint disease of osteoarthritis in the Riau archipelago ranged from $13.4 \%$ to $26.5 \%$ and the prevalence in Lingga is found higher than other city districts, otherwise Batarn has the lowest prevalence. As a consequence the prevalence of joint diseases of osteoarthritis that have been diagnosed by health personnel ranges from $7.3 \%-22.3, \%$, and the highest 
prevalence is pronounced in Lingga district, conversely the prevalence of Lowest in Batam city (Riskesdas, 2018).

Results of the report system of health records of the elderly group of Batam City Health office in 2016 the number of elderly aged 45-59 is 19,394, elderly people aged 60-69 are7,347 people, elderly aged $>70$ is 2,515 with the highest number of elderly in Tanjung Sengkuang Puskesmas with the number of 4,238 and the second in Sei Lekop Puskesmas with the amount of 3,639 people and third in the health center behind Padang with the number of 3,282 inhabitants, the data of the number of elderly enclosed (Dinas Kesehatan Kota Batam, 2018).

The impact that will occur in elderly with osteoarthritis is prone to decline in musculoskeletal function. The function of a joint cartilage has decreased so that the cartilage will thin and result in joint stiffness. Joint stiffness If notcan interfere with physical mobility in the elderly. Muscle joints when used to move then synovial fluid will increase and increase so that the elderly do the activity well. If the joint muscle is not used to perform the activity then the synovial fluid will remain so as not to increase (Sudoyo, Setiyohadi, Alwi, Simadibrata, \& Setiadi, 2014).

Joint pain is the most common complaint experienced by the elderly with impaired musculoskeletal system and is a long case that is very often tested. Usually there are many physical signs. Joint pain is often experienced by the elderly, so it is necessary to care and special attention to the elderly with joint pain. Such conditions also appear on all musculoskeletal systems and other networks that have to do with the possibility of occurrence of some groups of joint pains (Kholifah, 2016).

According to mobility is a person's ability to move freely, easily and regularly aiming to meet the needs of healthy living. Everyone needs to move. In addition to joint pain, another problem experienced by elderly with impaired musculoskeletal system has impaired mobility. One of the changes occurring in the musculoskeletal system and causing impaired mobility is the decrease in the scope of motion joints. The largest decrease in the scope of joint motion occurs in cervical and trunk, particularly in the lateral and rotational movement of extensions. Patients who have performed surgery can often cause problems that the presence of surgical injuries to the soft tissues can cause acute inflammatory processes and the presence of oedema and fibrosis in the muscles around the joints resulting in limited joint mobility, fracture caused the onset of pain, oedema in the lower limbs area as well as Decreased hamstring muscle fufled and muscles Quadriceps that cause especially degenerative diseases and for self-actualization (self-esteem and body image) limitation of motion in the knee joint area (Mubarak, Indrawati, \& Susanto, 2015).

Exercise Theraphy Joint Mobility is closely related to joints, because joints are essential to maximize joint mobility space, improve muscle performance, reduce the risk of injury and improve the nutrients of cartilage. Joints are a place of meeting two or more bones, so it can be concluded that the joints are the relationship or meeting of two or more bones that allow the movement of each other or that cannot move to each other.

Pain management can be done with pharmacological and non-pharmacological therapies. Pharmacological therapy using a sislooksigenase inhibitor (COX inhibitor) often causes side effects of gastrointestinal disorders e.g. Beartburn. In addition, its long-term use may result in gastrointestinal bleeding, peptic ulcer, perforation and kidney disorders. Research on osteoarthritis has also found that the largest cost associated with joint pain treatment comes from treating the side effects of the medication. Thus, non-pharmacological therapy may be appropriate to one alternative to treat joint pain in the elderly Exercise Theraphy Joint Mobility is non-pharmacological therapy. Mesort Mc Clokey and Bulecheck in Nursing Intervention Classification (NIC), Exercise Theraphy Joint Mobility is defined as the use of active or passive body movements to maintain or restore the flexibility of joints. The functional advantages of exercise therapy (joint mobility) to increase self-reliance, improve health, slow down disease processes, affect the quality of the knee joint pain and the level of mobility experienced by the elderly. Joint mobility is crucial for increasing self-reliance, improving health, slowing down 
disease processes, particularly degenarative diseases and for self-actualisation (self-esteem and body image).

Based on the descriptions above and from the existing data, the researcher looked at this problem very precisely in the review through a study. Then the author is interested to do the research with the title: Effect of Exercise Theraphy Joint Mobility to the level of knee pain joints Osteoarthritis in the elderly in the elderly Posyandu Padang.

\section{B. METHODS}

This study used the quasi own method with Pre and Post Test Without Control Research plan. Research is done by comparing the Post Test and Pre Test values. This research was conducted to know the influence of Exercise Theraphy Joint Mobility to decrease knee pain osteoarthritis in the elderly. The independent variable in this study is the Exercise Theraphy Joint Mobility.

\section{RESULT AND DISCUSSION}

Table 1. Age distribution of Osteoarthritis respondents

\begin{tabular}{ccc}
\hline Age & Frekuensi & (\%) \\
\hline 45-59 Year & 14 & 46,7 \\
60-74 Year & 13 & 43,3 \\
75-90 Year & 3 & 10,0 \\
\hline Total & 30 & 100 \\
\hline
\end{tabular}

According to Table 1 above, it is known that more than half of the respondents are in the 4559 year range of $46.7 \%$ or 14 respondents.

Table 2. Respondents gender distribution of Osteoarthritis

\begin{tabular}{ccc}
\hline Age & f & $\mathbf{( \% )}$ \\
\hline Male & 5 & 16,7 \\
Female & 25 & 83,3 \\
\hline Total & $\mathbf{3 0}$ & $\mathbf{1 0 0}$ \\
\hline
\end{tabular}

According to Table 2 above, it is known that generally the respondent is in the female gender of $83.3 \%$ or 25 respondents.

Table 3. Frequency of Osteoarthritis pain before done ROM

\begin{tabular}{lcc}
\hline Painful Osteoarthritis & f & (\%) \\
\hline Moderate Pain (4-6) & 24 & 80 \\
Mild Pain (1-3) & 6 & 20 \\
\hline & $\mathbf{3 0}$ & $\mathbf{1 0 0}$ \\
\hline
\end{tabular}

Based on the Table 3 above, it is noted that generally respondents who suffered a decrease in the pain of osteoarthritis before the ROM was at a moderate pain range of $80 \%$ or 24 respondents. 
18 | IJECA (International Journal of Education and Curriculum Application)

Vol. 1, No. 1, April 2018, pp. 14-20

\begin{tabular}{|c|c|c|}
\hline Painful Osteoarthritis & $\mathbf{f}$ & (\%) \\
\hline Moderate Pain (4-6) & 7 & 23,3 \\
\hline Mild Pain (1-3) & 23 & 76,7 \\
\hline & 30 & 100 \\
\hline
\end{tabular}

According to the Table 4 above, it is known that generally respondents who have decreased osteoarthritis joint pain ROM is in the range of $76.7 \%$ or 23 respondents.

\begin{tabular}{ccccc}
\multicolumn{5}{c}{ Table 5.Frequency distribution of painful joints of Osteoarthritis } \\
before and after the ROM is done
\end{tabular}

According to Table 5 above, shows that the score before and after is done ROM found result 1.43333. Based on the "test statistic" output in table 4.5 above, the P-value is known to be 0.000 . Because 0.000 value is smaller than $<0.05$, it can be concluded that "H0 is rejected", or in other words there is "the influence of exercise theraphy joint mobility of knee joint pain level of osteoarthritis in the elderly in the elderly Posyandu in Padang".

Based on the results of bivariate analysis, using the statistic dependent test of T-Test (Paired T-Test) obtained the result of a significant value of $0.000(\mathrm{P}=0.05)$ thus Ha received and $\mathrm{H} 0$ rejected, until it can be concluded that there is a influence of exercise theraphy joint mobility to the level of knee joint pain of osteoarthritis in the elderly in the elderly This research is done by giving a ROM treatment of osteoarthritis joint pain for approximately 2 weeks to be obtained average results before the ROM and after done a ROM that means a change in joint pain by doing a ROM. In this research researchers compare osteoarthritis joint pain

Before and after the ROM. From the results of the research done before the average ROM the respondent experienced moderate pain. Once the average ROM is done, the patient has mild pain. This is in accordance with the theory conveyed by Sumintarsih the exercise of the ROM can increase muscle strength can also improve the balance in the elderly, because the exercise of the ROM can increase the gain, endurance, and flexibility of the joints, so that the decreased musculoskeletal system can be 2014 corrected Balance is recommended for the elderly as it relates to the attitude of maintaining a balanced state while being silent or moving. Seniors who have physical fitness are required not to rely on others, and are expected to still be able to stand up and run well (Sumintarsih, 2006).

This is in accordance with the theory found in the association of Rheumatologists in Indonesia or IRA (2015) of osteoarthritis management, which is non-pharmacological therapy, which is physical therapy, such as exercise improvement in the scope of joint movement, muscle strength (QUADRISEP/groin) and joint mobility aids. Previous research on ROME was also conducted by Ulliya with the results of the influence of ROM exercises on the flexibility of elderly joints. ROM capable (1) maintain muscular ability, (2) Maintain joint movement, (3) Blood circulation, (4) Avoid defects. The ROM exercises increase the blood flow to the joint kapsula and increase the flexibility of joints so that the pain can be reduced even resolved (Mas'adah, 2017).

Exercise ROM is a simple activity that is able to give a big effect to changes in pain scale. In addition, the painful scale difference before and after the ROM exercises Can be used as a 
benchmark. It can be concluded if a ROM exercise is capable of affecting changes in the pain of osteoarthritis while maintaining a range of joint motion so that there is improvement in the area of problematic joints.

\section{CONCLUSION AND SUGGESTIONS}

Based on the results of the study and the description of the discussion in previous chapters can be concluded as follows: 1) respondents who have changed the pain of osteoarthritis before the ROM is in the range of moderate pain is $80 \%$ or 24 respondents. 2) respondents who have changed the pain of osteoarthritis after the ROM is in the range of mild pain of $76.7 \%$ or 23 respondents. 3) There is the influence of exercise theraphy joint mobility to the level of knee joint pain osteoarthritis in the elderly in elderly Posyandu in the Batam field in 2018 (P-value = $0.000<(\alpha 0.05)$

In addition to the conclusion in this research, researchers also have some advice that will be given to various parties to improve the method of delivery/program of therapy and to build awareness to various life human beings. Some of these suggestions are as follows: 1) For Padang back Health, the institution of the rear health center is expected to make the research result as one way toApplying a ROM exercise to decreased osteoarthritis joint pain in elderly patients, through the exercise of this ROM is expected to give maximum change for patients suffering from osteoarthritis; 2) For nursing Sciences particularly Posyandu behind Padang, this research is expected to health care personnel in the area of Padang rear Puskesmas provides health promotion about osteoarthritis related to family support in the form of counseling, the dissemination of leaflets and other health promotional media that aims to achieve quality of life in elderly osteoarthritis. This research can also contribute and development of nursing, as a material to take the policy on the influence of exercise theraphy joint mobility to the level of knee joint pain osteoarthritis in the elderly. This research is also expected to use the Range of Motion (ROM) exercises as a nonpharmacological intervention in osteoarthritis, so that elderly pain figures due to osteoarthritis decreases are even resolved without any side effects to be feared; 3) For educational institutions, the results of the research is suggested can be used as reference material library and information material especially about the influence of exercise theraphy joint mobility of knee joint pain level osteoarthritis in elderly in elderly posyandu; 4) For further researchers, the results of this research can be used as evidence based and additional information to develop further research on oxygen saturation, then researchers can also conduct researchAbout the effect of exercise theraphy joint mobility on the level of knee joint pain osteoarthritis in the elderly in elderly Posyandu with variables that affects the occurrence of the knee joint osteoatritis including age, sex, history of knee trauma, obesity, physical activity, work habits with heavy burdens.

\section{ACKNOWLEDGMENT}

A thank you researchers say to the lecturers STIKes Awal Bros Batam who have guided and gave directions so that the research can be carried out well and the party to Elderly Padang Posyanduworkshop that has given permission to conduct research on the resident who is undergoing rehabilitation. 


\section{REFERENCES}

Riskesdas. (2013). Badan Penelitian Dan Pengembangan Kesehatan Kementrian Kesehatan Ri. Jakarta: Laporan Nasional 2013, 87-90. Https://Doi.Org/1 Desember 2013

Badan Pusat Statistik. (2014). Statistik Indonesia. Statistical Yearbook Of Indonesia, Vol. 6, Pp. 78-79. Https://Doi.Org/10.3389/Fpsyg.2015.00002

Candra Widyanto, F. (2014). Keperawatan Komunitas Dengan Pendekatan Praktis. In Nuha Medika. Https://Doi.Org/10.1080/10837450902911929

Dinas Kesehatan Kota Batam. (2018). Profil Kesehatan Kota Batam Tahun 2018. Profil Kesehatan Kota Batam, (54), 38-74. Https://Doi.Org/10.1016/J.Ajog.2006.12.019

Kholifah, S. N. (2016). Modul Bahan Ajar Cetak Keperawatan: Keperawatan Gerontik. In Kementerian Kesehatan Republik Indonesia. $\quad$ Retrieved From Https://Id.Scribd.Com/Document/332269062/Strategi-Untuk-Promosi-Kesehatan-DanKesejahteraan-Lansia

Mas'adah, M. (2017). Model Senam Rematik Sebagai Upaya Peningkatan Aktifitas Fungsional Lansia Di Pstw Puspakarma Mataram. Adi Husada Nursing Journal, 3(1), 28. Https://Doi.Org/10.37036/Ahnj.V3i1.73

Mubarak, W. I., Indrawati, L., \& Susanto, J. (2015). Buku Ajar Ilmu Keperawatan Dasar. In Buku 1. Https://Doi.Org/10.1111/Ecoj.12426

Nugroho Wahjudi. (2015). Keperawatan Gerontik Dan Geriatrik Edisi 3. Jakarta: Egc.

Riskesdas. (2018). Kemenkes Ri. Profil Kesehatan Indonesia 2017. Data Dan Informasi. Kementrian Keseahtan Ri; 2018. In Jurnal Ilmu Kesehatan.

Spetz, J., Tellez, M., \& Fulton, B. (2016). Global Human Resources For Health. Https://Doi.Org/10.1142/9789813140530_0002

Sudoyo, A. W., Setiyohadi, B., Alwi, I., Simadibrata, M., \& Setiadi, S. (2014). Buku Ajar Ilmu Penyakit Dalam Edisis Vi. In Interna Publishing. Https://Doi.Org/10.1111/J.1365-2958.2011.07583.X

Sumintarsih. (2006). Kebugaran Jasmani Untuk Lanjut Usia. In Kebugaran Jasmani Untuk Lanjut Usia (Pp. 147-160).

Theresia, M. (2014). Theresia, M. Gambaran Tingkat Kepatuhan Kunjungan Antenatal Care Pada Ibu Hamil Trimester Iii Di Puskesmas Kulonprogo. Jurnal ; 2014. Jurnal Keperawatan. Https://Doi.Org/E-Issn 2443-0900

WHO. (2015). World Health Statiscs 2015. In Ekp (Vol. 13). 